\title{
ANION PERMEABILITY OF THE INHIBITORY SUBSYNAPTIC MEMBRANE OF THE SPINAL MOTONEURON OF THE TOAD
}

\author{
Shiushi MATSUURA* and Katsuaki Endo \\ Department of Physiology, Faculty of Medicine, Kyoto University, Kyoto, Japan
}

\begin{abstract}
Summary 1. Single microelectrodes filled with solutions containing various anions were inserted into toad spinal motoneurons and used for both the electrophoretic injection of anions and for intracellular recording.

2. Judging from the effect of anion injections on the IPSP's, the activated inhibitory subsynaptic membrane was found to be permeable to $\mathrm{Br}^{-}, \mathrm{I}^{-}$, $\mathrm{Cl}^{-}, \mathrm{No}_{2}^{-}, \mathrm{NO}_{3}^{-}, \mathrm{N}_{3}^{-}, \mathrm{ClO}_{4}^{-}, \mathrm{SCN}^{-}, \mathrm{OCN}^{-}, \mathrm{ClO}_{3}^{-}$, and $\mathrm{HCO}_{2}^{-}$ions. 3. $\mathrm{BrO}_{3}^{-}, \mathrm{F}^{-}, \mathrm{HSO}_{3}^{-}, \mathrm{HCO}_{3}^{-}, \mathrm{CH}_{3} \mathrm{CO}_{2}^{-}, \mathrm{SO}_{4}{ }^{2-}, \mathrm{H}_{2} \mathrm{PO}_{4}^{-}, \mathrm{HPO}_{4}{ }^{2-}$ and citrate ions were found to be impermeable through the activated inhibitory subsynaptic membrane. The ineffectiveness of injection of $\mathrm{HS}^{-}$ ions on the IPSP was confirmed.

4. The time constants of the IPSP recovery after injections were evaluated for nine penetrating anions. Then a sequence was determined for the order of their relative ability to penetrate the motoneuron membrane: It is $\mathrm{Br}^{-}>\mathrm{OCN}^{-}>\mathrm{NO}_{3}^{-}>\mathrm{NO}_{2}^{-}>\mathrm{SCN}^{-}>\mathrm{Cl}^{-}>\mathrm{HCO}_{2}^{-}>\mathrm{I}^{-}>$ $\mathrm{ClO}_{3}^{-}$.

5. Results obtained in the present investigation were compared with those from studies on cat spinal motoneurons and goldfish Mauthner cells.
\end{abstract}

Coombs, et al. (1955) observed that the inhibitory postsynaptic potential (IPSP) of the spinal motoneuron of the cat changed from a hyperpolarizing type to a depolarizing one when $\mathrm{Cl}^{-}, \mathrm{Br}^{-}, \mathrm{NO}_{3}^{-}$, and $\mathrm{SCN}^{-}$ions were injected intracellularly. These results were explained by assuming that the activated inhibitory subsynaptic membrane is permeable to these ions. On the other hand, it was found that the injection of $\mathrm{HCO}_{3}{ }^{-}, \mathrm{CH}_{3} \mathrm{CO}_{2}{ }^{-}, \mathrm{SO}_{4}{ }^{2-}, \mathrm{H}_{2} \mathrm{PO}_{4}{ }^{2-}$ ions had no effect on the IPSP. Since the permeable ions are smaller in the hydrated form

Received for publication January 11, 1971

松裏修四，遠藤克昭

* Present adress: Department of Physiology, Osaka City University Medical School, Abenoku, Osaka 545, Japan 
than the impermeable ions, it was postulated that the activated inhibitory subsy-n aptic membrane is converted into a sieve-like structure having pores of a standard size. These results have been confirmed and extended to many other anions by ARAKi et al. (1961) and ITO et al. (1962). In their extensive investigation, it has been shown that anions are definitely separated into two categories, i.e., the one that can penetrate and the ones that cannot penetrate through the activated inhibitory subsynaptic membrane of spinal motoneurons of the cat. Research along this line has been further extended to the IPSP's of other central synapses, including those in the Mauthner cells of the goldfish (ASADA, 1963), in the neurons of the snail (KerKuT and THOMAS, 1964), in the neuromuscular junction of the crayfish (TAKEUCHI and TAKEUCHI, 1967) and in the cortical neuron of the cat (Kelly et al., 1969).

In the present investigation, anion permeability of the activated inhibitory subsynaptic membrane of the spinal motoneuron of the toad has been tested from the comparative physiological point of view. Furthermore, the time constant for diffusion of injected anions from the motoneuron has been evaluated according to the time course of the recovery of the IPSP after anion injection. It will be shown that between spinal motoneurons of the cat and toad, there is no essential difference in anion permeability of the inhibitory subsynaptic membrane but there are discrepancies in the relative anion permeability of the non-synaptic membrane.

\section{METHODS}

Toads anaesthetized with Nembutal $(25 \mathrm{mg} / \mathrm{kg})$ were used. They were firmly suspended in a rigid metal frame. The spinal cord was exposed and the 9 th and 10 th ventral and dorsal roots were cut and mounted on $\mathrm{Ag}-\mathrm{AgCl}$ electrodes for stimulation. In some cases, muscle nerves such as the tibial and peroneal nerves were prepared for orthodromic stimulation, the dorsal roots being kept intact. In some later experiments excised spinal cords were used. They were kept in a Ringer's solution through which a gas mixture consisting of $95 \% \mathrm{O}_{2}$ and $5 \% \mathrm{CO}_{2}$ was continuously bubbled.

Glass microelectrodes were filled with the solutions listed in Table 1, which contained various anions as either potassium or sodium salts. Potassium salts were preferred, unless their solubility was very slight. The electrical resistance of the microelectrode used was usually $10-20 \mathrm{M} \Omega$.

The microelectrode was connected to a current generator through a $100 \mathrm{M} \Omega$ resistor, and anions were injected into the motoneuron by the passage of currents of $1-5 \times 10^{-8}$ A for $30-120$ sec. The intracellular potentials were recorded through the same electrode that served for the injection. Following the application of the current, a transient change in the tip potential of the microelectrode was frequently observed and this artifact disturbed the measurement of the membrane potential 
Table 1. Solutions used for filling microelectrodes.

\begin{tabular}{lclc}
\hline Substance & Concentration (M) & Substance & Concentration (M) \\
\hline $\mathrm{KBr}$ & 1 & $\mathrm{NaBrO}_{3}$ & 1.8 \\
$\mathrm{KI}$ & 1 & $\mathrm{NaF}$ & 0.8 \\
$\mathrm{KCl}$ & 1 & $\mathrm{NaHCO}_{2}$ & 2 \\
$\mathrm{KNO}_{2}$ & 1 & $\mathrm{NaHSO}_{3}$ & 3 \\
$\mathrm{KNO}_{3}$ & 2 & $\mathrm{KHCO}_{3}$ & 1 \\
$\mathrm{NaN}_{3}$ & 2 & $\mathrm{KCH}_{3} \mathrm{CO}_{2}$ & 1 \\
$\mathrm{NaClO}_{4}$ & 1 & $\mathrm{~K}_{2} \mathrm{SO}_{4}$ & 0.6 \\
$\mathrm{KSCN}$ & 2 & $\mathrm{KH}_{2} \mathrm{PO}_{4}$ & 1 \\
$\mathrm{NaHS}$ & 1 & $\mathrm{~K}_{2} \mathrm{HPO}_{4}$ & 1 \\
$\mathrm{KOCN}$ & 1 & $\mathrm{~K}-\mathrm{citrate}$ & 2 \\
$\mathrm{NaClO}$ & & & \\
\hline
\end{tabular}

change immediately after the cessation of the current. In order to compensate for this artifact potential, potential changes were recorded by applying the same current just outside the motoneuron. Usually, electrodes with large artifact potentials were not used.

For intracellular potential recording, a cathode follower with a negative capacitance compensation was used and the output was connected to a oscilloscope through differential AC and DC amplifiers. The current passed through the microelectrode for injections was recorded by another differential DC amplifier. The resting potential was registered by an inkwriting recorder.

All experiments were carried out at room temperature, $15-19^{\circ} \mathrm{C}$.

RESULTS

\section{Penetrating anions}

The injections of $\mathrm{Br}^{-}, \mathrm{I}^{-}, \mathrm{Cl}^{-}, \mathrm{NO}_{2}^{-}, \mathrm{NO}_{3}^{-}, \mathrm{N}_{3}^{-}, \mathrm{ClO}_{4}^{-}, \mathrm{SCN}^{-}, \mathrm{OCN}^{-}$, $\mathrm{ClO}_{3}^{-}$and $\mathrm{HCO}_{2}^{-}$ions by a hyperpolarizing current of $1-5 \times 10^{-8}$ A for 30-120 sec readily resulted in a reversal of the IPSP. Figure 1 shows an example of the reversal of the IPSP by the injection of $\mathrm{NO}_{2}^{-}$ions. Record A shows the control IPSP recorded from a motoneuron evoked by stimulation of the 10th dorsal root. Records B-G were obtained at successive intervals after application of $2 \times 10^{-8} \mathrm{~A}$ for $60 \mathrm{sec}$. Immediately after the cessation of the current, the reversal of the IPSP was so great that it attained the level of the threshold depolarization of the motoneuron and a spike potential was initiated as shown in Record B. Thereafter, the reversed IPSP decreased in size $(C$ and $D)$ and eventually returned to the original hyperpolarizing type $(E-G)$. A diphasic stage was observed when the reversed IPSP turned back to a hyperpolarization, as pointed out by CoomBS et al. (1955) and ARAKI et al. (1961). Records I-K in Fig. 1 were obtained with high and low amplification after the second injection of $\mathrm{NO}_{2}^{-}$ions by a current of 
$1 \times 10^{-8} \mathrm{~A}$ for $60 \mathrm{sec}$ in the same motoneuron, the antidromic spike being evoked at the end of the sweep.

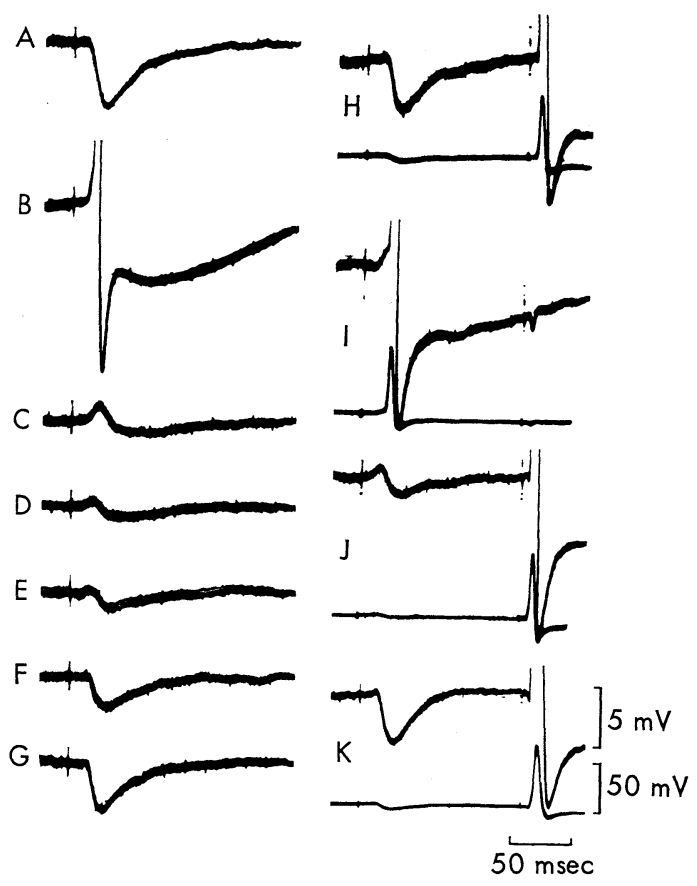

Fig. 1. Effects of injection of $\mathrm{NO}_{2}{ }^{-}$ions on the IPSP. A shows the control IPSP from a motoneuron evoked by stimulation of the 10 th dorsal root. B, C, D, E, F and G were obtained at $8,16,36,48,70$, and $260 \mathrm{sec}$, respectively, after the application of an inward current of $2 \times 10^{-8} \mathrm{~A}$ for $60 \mathrm{sec}$ through the intracellular microelectrode filled with a $1 \mathrm{M} \mathrm{KNO}$ solution. $\mathrm{H}-\mathrm{K}$ show the effect of the second injection of $\mathrm{NO}_{2}{ }^{-}$ions on the same cell. H shows the IPSP together with antidromically evoked spike potential before, and $\mathrm{I}-\mathrm{K}$ show it after, the passage of a hyperpolarizing current of $1 \times 10^{-8} \mathrm{~A}$ for $60 \mathrm{sec}$. Note the double beam recording, the upper and lower beams being in high and low amplification, respectively.

The change in the size of the IPSP by the injection of $\mathrm{NO}_{2}^{-}$ions together with that of the spike potentials and of the resting potential is plotted in Fig. 2. The size of the IPSP was measured by the amplitude at a fixed time corresponding to the peak of the largest depolarizing IPSP. As is seen in Fig. 2, the IPSP was recovered in an approximately exponential way. The recovery of the IPSP after the injection of $\mathrm{NO}_{2}$ - ions was almost complete in the second trial. On the other hand, the final value of the IPSP after the first trial was slightly different from the original one, as was often observed after injections of penetrating anions in the present investigation. 


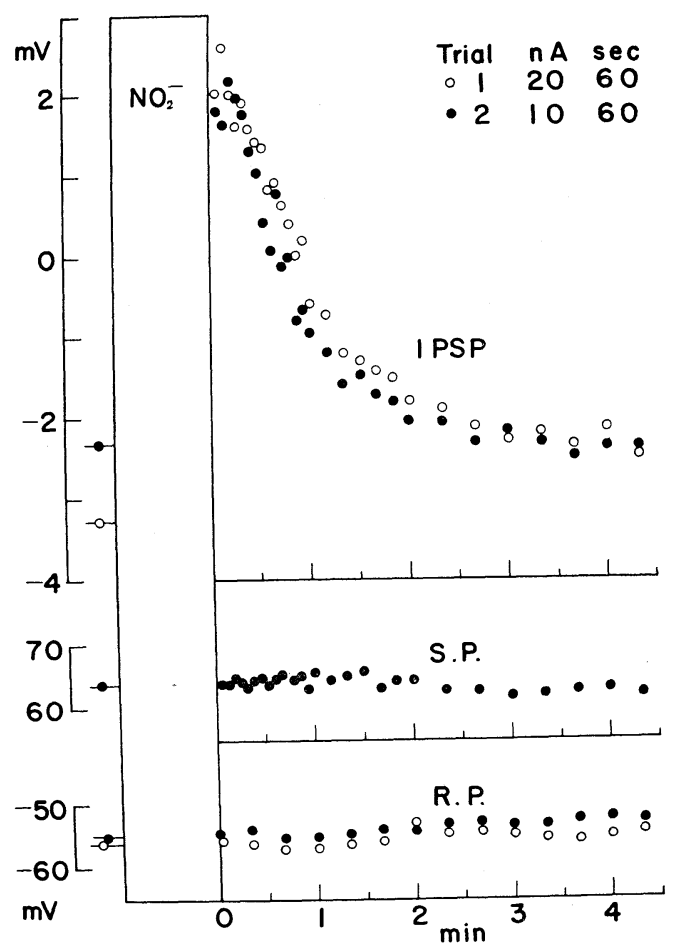

Fig. 2. Plot of the sizes of IPSP's, antidromically evoked spike potentials (S.P.) and resting potentials (R.P.) before and after injections of $\mathrm{NO}_{2}-$ ions. The plots were obtained from the series partly illustrated in Fig. 1.

While an injection of penetrating anions produced a great change in the IPSP, no significant change in the spike potential or in the EPSP was observed, unless the resting potential of the motoneuron was depressed by the damaging effect of the injection. The ineffectiveness of the penetrating anions on the spike potential and EPSP was also observed when nonpenetrating anions were injected.

The toxic effect of $\mathrm{N}_{3}{ }^{-}$ions reported by ARAKI et al. (1961) was found to be rather slight in the present investigation and the reversal of the IPSP after injection was demonstrated in three cells: The recovery of the IPSP followed an exponential curve approximately. Though the injection of $\mathrm{ClO}_{4}^{-}$ions was technically difficult (ARAKI et al., 1961), it was possible to observe the reversal of the IPSP after their injection into four cells.

The effect of the above-mentioned anions upon the IPSP indicates that they can penetrate the activated inhibitory subsynaptic membrane. These penetrating ions are, therefore, labelled by plus signs in Table 2 . 
Table 2. Effects of anion injections on the IPSP.

\begin{tabular}{|c|c|c|c|c|}
\hline Ion & $\begin{array}{l}\text { Relative } \\
\text { hydrated } \\
\text { size }\end{array}$ & $\begin{array}{l}\text { IPSP } \\
\text { effect }\end{array}$ & $\begin{array}{l}\text { No. of } \\
\text { injections }\end{array}$ & $\begin{array}{l}\text { No. of } \\
\text { cells }\end{array}$ \\
\hline $\mathrm{Br}^{-}$ & 0.94 & + & 12 & 4 \\
\hline $\mathrm{I}^{-}$ & 0.94 & + & 4 & 4 \\
\hline $\mathrm{Cl}^{-}$ & 0.96 & + & 9 & 7 \\
\hline $\mathrm{NO}_{2}{ }^{-}$ & 1.02 & + & 17 & 6 \\
\hline $\mathrm{NO}_{3}^{-}$ & 1.03 & + & 14 & 5 \\
\hline $\mathrm{N}_{3}^{-}$ & 1.07 & + & 3 & 3 \\
\hline $\mathrm{ClO}_{4}^{-}$ & 1.09 & + & 5 & 4 \\
\hline $\mathrm{SCN}^{-}$ & 1.11 & + & 9 & 3 \\
\hline $\mathrm{HS}^{-}$ & 1.13 & - & 5 & 2 \\
\hline $\mathrm{OCN}^{-}$ & 1.14 & + & 5 & 3 \\
\hline $\mathrm{ClO}_{3}^{-}$ & 1.14 & + & 5 & 3 \\
\hline $\mathrm{BrO}_{3}^{-}$ & 1.32 & - & 3 & 2 \\
\hline $\mathrm{F}^{-}$ & 1.33 & - & 2 & 2 \\
\hline $\mathrm{HCO}_{2}{ }^{-}$ & 1.35 & + & 4 & 4 \\
\hline $\mathrm{HSO}_{3}^{-}$ & 1.47 & - & 2 & 2 \\
\hline $\mathrm{HCO}_{3}^{-}$ & 1.65 & - & 5 & 3 \\
\hline $\mathrm{CH}_{3} \mathrm{CO}_{2}^{-}$ & 1.80 & - & 3 & 2 \\
\hline $\mathrm{SO}_{4}^{2-}$ & 1.84 & - & 4 & 3 \\
\hline $\mathrm{H}_{2} \mathrm{PO}_{4}^{--}$ & 2.04 & - & 2 & 2 \\
\hline $\mathrm{HPO}_{4}{ }^{2-}$ & 2.58 & - & 2 & 2 \\
\hline $\mathrm{C}_{6} \mathrm{H}_{5} \mathrm{O}_{7}{ }^{3-}$ & 3.08 & - & 5 & 3 \\
\hline
\end{tabular}

\section{Nonpenetrating anions}

After the injection of $\mathrm{BrO}_{3}^{-}, \mathrm{F}^{-}, \mathrm{HSO}_{3}^{-}, \mathrm{CH}_{3} \mathrm{CO}_{2}^{-}, \mathrm{SO}_{4}^{-}, \mathrm{H}_{2} \mathrm{PO}_{4}^{-}, \mathrm{HPO}_{4}{ }^{2-}$, citrate and $\mathrm{HS}^{-}$ions, the IPSP remained nearly the same or increased slightly in size. In Fig. 3, the effect of the injection of $\mathrm{CH}_{3} \mathrm{CO}_{2}^{-}$ions is shown. Record $\mathrm{A}$ gives the control IPSP produced by the stimulation of the 9 th dorsal root. An antidromic spike is shown at the right of the sweep. An inward current of $1.8 \times$ $10^{-8} \mathrm{~A}$ was applied through the microelectrode. $\mathrm{B}$ and $\mathrm{C}$ are specimen records obtained at 20 and $120 \mathrm{sec}$, respectively, after the cessation of the current. The sizes of the IPSP, spike potential and resting potential are plotted in Fig. 4. As is seen in this figure, the IPSP increased in size immediately after the cessation of the current and then went back to its original size within a few minutes. However, there was no significant change in the spike potential and the resting potential. The increase in the hyperpolarization of the IPSP after the injection may be attributable to the depletion of $\mathrm{Cl}^{-}$ions from the cell by the hyperpolarizing current as suggested by ARAKI et al. (1961).

Since CoOmBs et al. (1955) could not exclude the possibility that $\mathrm{HCO}_{3}^{-}$ ions were partly responsible for changing the IPSP in the depolarizing direction, this ion species was carefully tested by ARAKI et al. (1961). The latter authors found that in the first series of successive injections of $\mathrm{HCO}_{3}^{-}$ions in one cell 


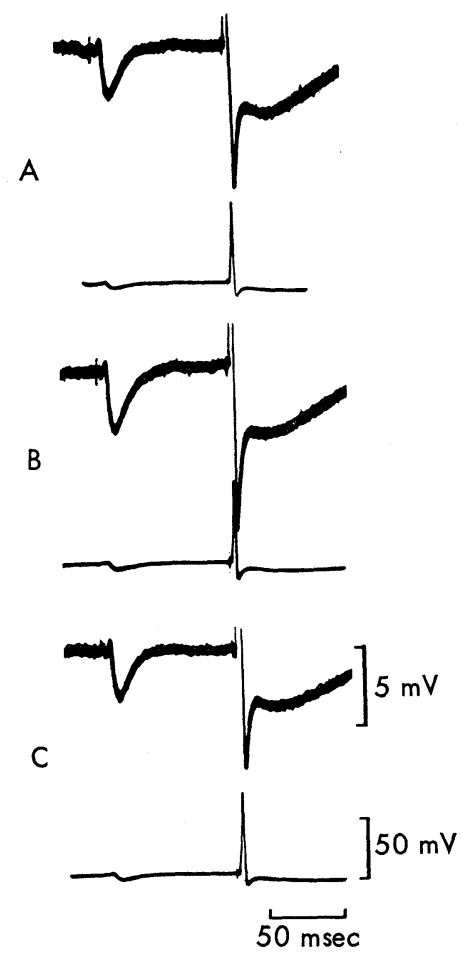

Fig. 3. Effect of injection of $\mathrm{CH}_{3} \mathrm{CO}_{2}{ }^{-}$ions on the IPSP. A shows the control IPSP evoked by the stimulation of the 9 th dorsal root, followed by an antidromically evoked spike potential. They are recorded in high and low amplification in the upper and lower beams, respectively. $\mathrm{B}$ and $\mathrm{C}$ were obtained at 20 and $120 \mathrm{sec}$, respectively, after the application of an inward current of $1.8 \times 10^{-8} \mathrm{~A}$ through the microelectrode filled with a $1 \mathrm{M} \mathrm{KCH}_{3} \mathrm{CO}_{2}$ solution.

a small reduction of the IPSP was observed, the reduction being progressive with a maximum of about $30 \mathrm{sec}$ after the injection. In the later series the IPSP turned into a depolarizing potential following a time course similar to that in the initial series. In the present investigation, however, these unique changes in the size of the IPSP were not produced in five trials of injection of $\mathrm{HCO}_{3}{ }^{-}$ions into three cells, and no appreciable change in the IPSP was observed.

The ineffectiveness of $\mathrm{HS}^{-}$ions in converting the IPSP to a depolarizing response in spite of the small hydrated size of this ion species was reported by Iто et al. (1962) and later by AsADA (1963). This has been confirmed also in the toad spinal motoneuron in the present investigation.

Since the injections of the above-mentioned anions are ineffective in changing the IPSP in the depolarizing direction, it can be concluded that the activated inhibitory subsynaptic membrane is impermeable to these anions. They are labelled by minus signs in Table 2 . 


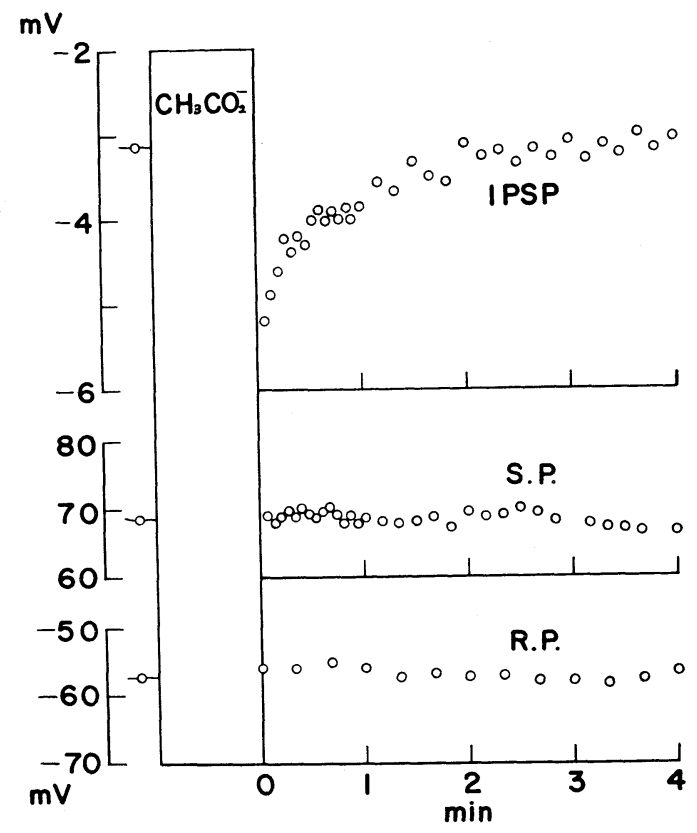

Fig. 4. Plots of the sizes of IPSP's, antidromic spike potentials (S.P.) and resting potentials (R.P.) before and after the injection of $\mathrm{CH}_{3} \mathrm{CO}_{2}{ }^{-}$ions. The plots were obtained from records partly illustrated in Fig. 3.

\section{Recovery of the IPSP after anion injection}

With penetrating anions the time course of the IPSP after anion injection was assumed to be of an exponential nature. In order to test the presumed exponential time course, the sizes of the IPSP were measured as the algebraic difference from the values obtained at the end of the recovery and these were plotted logarithmically against the time after cessation of the current. Figure 5 illustrates the time course of the recovery of the IPSP as plotted in this way after two trials of $\mathrm{NO}_{2}^{-}$injection as shown in Figs. 1 and 2. As is seen in Fig. 5, the points fall approximately along straight lines with time constants of 52 and $47 \mathrm{sec}$ for the first and the second trials of $\mathrm{NO}_{2}{ }^{-}$injection, respectively. It was not possible to obtain reliable values for the time constant of the IPSP recovery after injections of $\mathrm{N}_{3}^{-}$ and $\mathrm{ClO}_{4}^{-}$ions. For other anion species which penetrate through the activated inhibitory subsynaptic membrane, the time constants thus measured showed a considerable range as indicated in Table 3.

CoOmBs et al. (1955) reported that the time course of the recovery of the IPSP after the penetrating anion injection is attributable to a fall of the injected anion concentration as the ions diffuse outward across the motoneuron membrane. Furthermore, it has been shown by ARAKI et al. (1961) that this diffusion of injected ions takes place for the most part across the non-synaptic membrane, the activated 


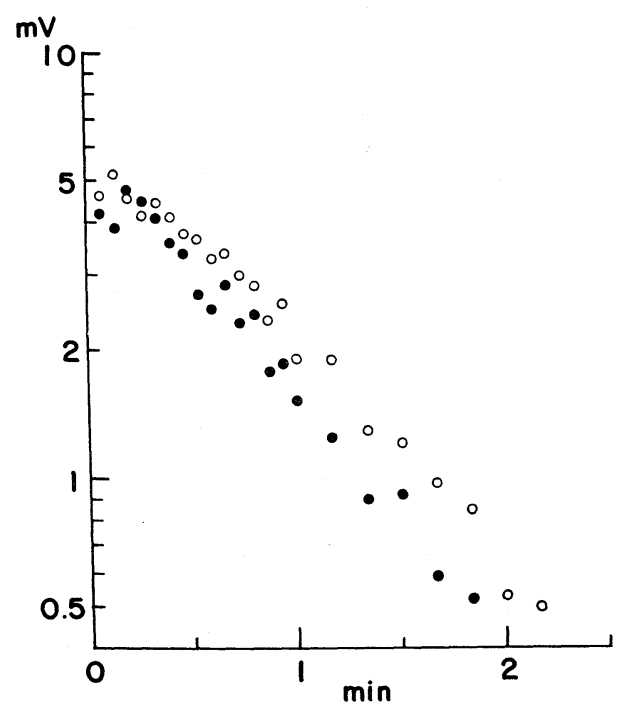

Fig. 5. Logarithmic plot of the IPSP size in the course of recovery after the injection of $\mathrm{NO}_{2}{ }^{-}$ions. Plots are obtained from two trials in the cell that is partly illustrated in Figs. 1 and 2.

Table 3. Time constant of IPSP recovery.

\begin{tabular}{lccccc}
\hline $\begin{array}{l}\text { Anion } \\
\text { species }\end{array}$ & $\begin{array}{c}\text { No. of } \\
\text { cells }\end{array}$ & $\begin{array}{c}\text { No. of } \\
\text { trials }\end{array}$ & $\begin{array}{c}\text { Mean time } \\
\text { constant } \\
(\mathrm{sec})\end{array}$ & $\begin{array}{c}\text { Range } \\
(\mathrm{sec})\end{array}$ & $\begin{array}{c}\text { Relative } \\
\text { ability to } \\
\text { penetrate }\end{array}$ \\
\hline $\mathrm{Br}^{-}$ & 4 & 12 & $34.8 \pm 4.5$ (S.D.) & $29-42$ & 1.58 \\
$\mathrm{OCN}^{-}$ & 3 & 5 & $37.6 \pm 2.8$ & $35-42$ & 1.46 \\
$\mathrm{NO}_{3}{ }^{-}$ & 5 & 14 & $42.6 \pm 5.8$ & $30-56$ & 1.29 \\
$\mathrm{NO}_{2}^{-}$ & 6 & 17 & $45.6 \pm 4.3$ & $36-57$ & 1.20 \\
$\mathrm{SCN}^{-}$ & 3 & 9 & $49.0 \pm 5.9$ & $43-61$ & 1.12 \\
$\mathrm{Cl}^{-}$ & 7 & 9 & $54.6 \pm 7.1$ & $41-63$ & 1.00 \\
$\mathrm{HCO}_{2}^{-}$ & 4 & 4 & $63.0 \pm 4.8$ & $58-71$ & 0.87 \\
$\mathrm{I}^{-}$ & 4 & 4 & $65.5 \pm 7.6$ & $55-76$ & 0.83 \\
$\mathrm{ClO}_{3}^{-}$ & 3 & 5 & $85.2 \pm 8.3$ & $69-91$ & 0.64 \\
\hline
\end{tabular}

inhibitory subsynaptic membrane forming an insignificant part in this respect. Accroding to the constant-field theory (Goldman, 1943; HodGKIN and KATZ, 1949), the time constant of the anion escape from the cell is related to the permeability coefficient of the membrane, to the ratio of the cell volume to surface area, and to the membrane potential. Motoneurons tested in the present investigation had large resting potentials (larger than $53 \mathrm{mV}$ ) and tolerated the injection for a considerable time, so that they could be assumed to be large cells. Therefore, the permeability coefficient of the membrane may be the only important factor in 
determining the above-mentioned time constant. Thus, the time constant of the IPSP recovery can be assumed as reciprocally proportional to the permeability coefficient through the whole surface area of the motoneuron (ARAKI et al. 1961). The relative values of the permeability coefficients thus calculated are given in Table 3.

\section{DISCUSSION}

It has been shown in the present investigation that the anion penetrability of the activated inhibitory subsynaptic membrane of the spinal motoneuron of the toad is essentialy the same as that found in the spinal motoneuron of the cat reported by ARAKI et al. (1961) and Ito et al. (1962) and also in the Mauthner cell of the goldfish described by AsADA (1963). The exceptional permeability of $\mathrm{HCO}_{2}{ }^{-}$ions has been reinforced by the finding of the present study. In their investigation of the motoneuron of the cat, ARAKI et al. (1961) found that $\mathrm{HCO}_{2}^{-}$ ions were permeable through the activated inhibitory subsynaptic membrane in spite of their large hydrated size. To explain this exceptional behaviour, they suggested that the relative hydrated size of $\mathrm{HCO}_{2}^{-}$ions might be smaller at $38^{\circ} \mathrm{C}$, the body temperature of the cat, than at $25^{\circ} \mathrm{C}$ where the conductance measurement was made. Their alternative explanation was that the $\mathrm{HCO}_{2}^{-}$ions might have an ellipsoidal shape with an axis smaller than the pore diameter. Since all present experiments in the toad spinal cord were performed at room temperature, 15$19^{\circ} \mathrm{C}$, the exceptional behaviour of $\mathrm{HCO}_{2}^{-}$ions cannot be explained by the former hypothesis. Therefore, the latter hypothesis seems to be acceptable. The same conclusion has been reported by ASADA (1963). The exceptional behaviour of $\mathrm{HS}^{-}$ions, being ineffective on the IPSP despite the small hydrated size, reported by Iто et al. (1962) and described by Asada (1963), has been confirmed in the present investigation. The most probable explanation for this phenomenon may be that $\mathrm{HS}^{-}$ions cannot exist free in the cell as suggested by ITO et al. (1962).

The results of the present investigation as well as those reported by ARAKI et al. (1961), Iто et al. (1962) and AsADA (1963) indicate that anions are clearly separated into penetrating and non-penetrating ones through the activated inhibitory subsynaptic membrane. There are no transitional ions forming an intermediate zone. However, Kerkut and ThOMAs (1964) have shown that $\mathrm{BrO}_{3}^{-}$ ions caused a very slight decrease in the reversal potential of the IPSP in the neurons of the snail, so this ion species may lie in an intermediate zone between the penetrating and non-penetrating anions. TAKEUCHI and TAKEUCHI (1967) have also demonstrated that $\mathrm{BrO}_{3}^{-}$ions are slightly permeable in the crayfish inhibitory neuromuscular junction. The structure of the activated subsynaptic membrane of the snail neuron and of the crayfish neuromuscular junction may be somewhat different from that of the cat and toad motoneuron and of the goldfish Mauthner cell. Recently, significantly different results have been reported in the study on 
anion permeability of cortical neurons of the cat (KELLY et al. 1969). All inorganic univalent anions tested, except $\mathrm{IO}_{3}^{-}$, and organic univalent anions (mainly of aliphatic and aromatic acids) have been found to be capable of producing a reversal of cortical IPSP's by diffusion from microelectrodes.

Concerning the anion permeability of the non-synaptic motoneuron membrane, it is interesting to compare the time constant of the IPSP recovery listed in Table 2 with that reported by ARAKI et al. (1961). It has been found in the present investigation that the order of the relative permeability for the non-synaptic motoneuron membrane in the toad is $\mathrm{Br}^{-}>\mathrm{OCN}^{-}>\mathrm{NO}_{3}{ }^{-}>\mathrm{NO}_{2}{ }^{-}>\mathrm{SCN}^{-}>\mathrm{Cl}^{-}>\mathrm{HCO}_{2}^{-}$ $>\mathrm{I}^{-}>\mathrm{ClO}_{3}^{-}$, while that of the cat motoneuron membrane has been found by ARAKI et al. (1961) to be $\mathrm{Br}^{-}=\mathrm{SCN}^{-}>\mathrm{Cl}^{-}>\mathrm{NO}_{2}{ }^{-}>\mathrm{BF}_{4}^{-}>\mathrm{I}^{-}>\mathrm{NO}_{3}{ }^{-}>\mathrm{ClO}_{3}^{-}>$ $\mathrm{HCO}_{2}^{-}$. It should be noticed that $\mathrm{Br}^{-}$ions are the most permeable, while the permeability to $\mathrm{HCO}_{2}^{-}$and $\mathrm{ClO}_{3}{ }^{-}$ions is very low in both the cat and toad motoneuron membrane. However, discrepancies are found in the relative permeability to other penetrating anions between cat and toad motoneuron membranes, particulary for $\mathrm{Cl}^{-}, \mathrm{NO}_{3}^{-}$and $\mathrm{SCN}^{-}$ions. For the halide anions, the sequence of $\mathrm{Br}^{-}>\mathrm{Cl}^{-}>\mathrm{I}^{-}$holds true in both cases. Since the sequence of relative anion permeability of the toad motoneuron membrane is not in keeping with their hydrated size, the simple pore hypothesis (BOYLE and CONWAY, 1941) does not seem to be applicable. This is also the case with the cat motoneuron membrane.

Various hypothesis have appeared to explain the relative ionic permeability of biological membranes (e.g., Harris, 1956; Shanes, 1958; Mullins, 1959, 1960; EISENMAN, 1965). The applicability of various hypothesis to the relative anion permeability of the cat motoneuron membrane has been discussed by ARAKI et al. (1961). They have come to the conclusion that no single hypothesis based upon the hydrated size or the naked ion size or hydration energy can explain the sequence of the relative anion permeability of the cat motoneuron membrane. As SHANES (1958) has suggested, the sequence of anion permeability may be accounted for in terms of hydration energies and naked ion diameters. It may be not impossible to explain the sequence of the relative anion permeability found in the present investigation if one takes Shane's hypothesis into account.

The authors wish to thank Professor T. Araki for his kind advice and criticism which he gave throughout this investigation and for his help in preparing this manuscript.

\section{REFERENCES}

Araki, T., Ito, M. and Oscarsson, O. (1961) Anion permeability of the synaptic and nonsynaptic motoneuron membrane. J. Physiol., 159: 410-435.

AsadA, Y. (1963) Effects of intracellulary injected anions on the Mauthner cells of goldfish. Jap. J. Physiol., 13: 583-598.

Boyle, P. J. and Conway, E. J. (1941) Potassium accumulation in muscle and associated changes. J. Physiol., 100: 1-63. 
Coombs, J. S., EcCles, J. C. and FATt, P. (1955) The specific ionic movement across the motoneuronal membrane that produces the inhibitory postsynaptic potential. J. Physiol., 130: 326-373.

Eisenman, G. (1965) Proc. 23rd Intern. Congr. Physiol. Sci., Tokyo, Excerptra Med. Found., Amsterdam, 489-506.

Goldman, D. E. (1943) Potential, impedance, and rectification in membranes. J. Gen. Physiol., 27: $37-60$.

HARRIs, E. J. (1956) Transport and Accumulation in Biological Systems. Butterworths, London, 82-83.

Hodgkin, A. L. and KATz, B. (1949) The effect of sodium ions on the electrical activity of the giant axon of the squid. J. Physiol., 108: 37-77.

Ito, M. Kostyuk, P. G. and Oshima, T. (1962) Further study on anion permeability of inhibitory postsynaptic membrane of cat motoneurones. J. Physiol., 164: 150-156.

Kelly, J. S., Krnjevic, K., Morris M. E. and Yim, G. K. W. (1969) Anionic permeability of cortical neurones. Exp. Brain Res., 7: 11-31.

Kerkut, G. A. and Thomas, R. C. (1964) The effect of anion injection and changes in the external potassium and chloride concentration on the reversal potentials of the IPSP and acetylcholine. Comp. Biochem. Physiol., 11: 199-213.

Mullins, L. J. (1959) The penetration of some cations into muscle. J. Gen. Physiol., 42: 817830.

Mullins, L. J. (1960) Analysis of pore size in excitable membranes. J. Gen. Physiol., 43: Suppl. $1,105-117$.

ShANES, A. M. (1958) Electrochemical aspects of physiological and pharmacological action in excitable cells. Pharmacol. Rev., 10: 59-164.

TAKeUChI, A. and TAKeUCHI, N. (1967) Anion permeability of the inhibitory postsynaptic membrane of the crayfish neuromuscular junction. J. Physiol., 191: 575-590. 